\title{
Unsportsmanlike Conduct: 15-yard Penalty and Loss of Free Speech in Public University Sports Stadiums"
}

\section{INTRODUCTION}

In March 2005, a University of Kansas (KU) student and his three friends traveled to Columbia, Missouri, to watch their beloved Jayhawk men's basketball team take on archrival ${ }^{1}$ Missouri. $^{2}$ While this was not their first trip to the University of Missouri (MU) to attend an athletic

\begin{abstract}
* Christopher J. Kaufman. J.D. candidate 2010, University of Kansas School of Law; B.S 2005, University of Kansas. Thank you to Professor Stephen McAllister and the Law Review Staff and Editors for all of their hard work. I would also like to thank my family - to my wife Allison, sister Jennifer, and my parents for their constant love and support. Special thanks also to Andrew Wymore, Christian Green, and Rich Littrell for inspiring this Comment.

1. The rivalry between the University of Kansas and the University of Missouri is deeply rooted in the days of the American Civil War. Jonathan Kealing, Anatomy of a Rivalry, LAWRENCE J.-World, Nov. 23, 2007, at A1; see Bowen Kerrihard, America's Civil War: Missouri and Kansas, HISTORYNET.COM, http://www.historynet.com/americas-civil-war-missouri-and-kansas.htm/ (last visited Mar. 13, 2009). At the time, Kansas was a territory becoming a strong candidate for statehood and a region home to those who favored the abolition of slavery, also known as Jayhawkers. Kerrihard, supra. On the other side of the border, however, Missouri citizens began to fight against the abolitionist movement growing in Kansas and on August 21, 1863, William C. Quantrill led 450 of his Missouri followers (Bushwhackers) into Kansas and sacked the City of Lawrence. Id. "In 120 minutes, they had devastated the dusty town of 2,000 inhabitants and killed 150 of its male citizens. Many were gunned down before their wives and children; others died trapped in their flaming homes." Id. The fighting continued back and forth until the close of the war. Id. The rivalry has since carried over to the football field into what is today the second-longest rivalry in college football. Steve Wieberg, 'Border War' Stakes High for Missouri, Kansas, USA TODAY, Nov. 23, 2007, at 1C. One popular story in the rivalry occurred in 1950, when the two teams met in Columbia, Missouri, to play a game the day after a snowstorm that shut down the entire city. Austin Murphy, They Got Game, SI.COM, Nov. 20, 2007, available at http://sports illustrated.cnn.com/2007/football/ncaa/11/20/kansas.missouri1126. Conditions for the game became so frigid that Kansas coaches were forced to ask the Tigers if they had any extra clothing to spare for the game. Id. Missouri's equipment manager replied "Hell, no ... We hope you freeze your asses off." Id. So, in order to provide shelter for KU's players during the game, KU coaches had the team bus ram a padlocked gate at the stadium so it could be parked behind the team bench to block the wind. Id. The rivalry is so intense, that since the 1960 season, the schools have not agreed on their official win/loss record. Rick Dean, $K U$ vs MU-'Absolutely the Biggest,' TOPEKA CAP.-J., Nov. 23, 2007, at D1. That year, the Jayhawks were forced to forfeit their 23-7 win and the league title after KU used a player during the game who was deemed ineligible to compete after he accepted a plane ride from a $\mathrm{KU}$ booster the year before. $I d$.
\end{abstract}

2. Briefly in Sports: University OK's Handling of KU Student, TOPEKA CAP.-J., May 25, 2005, at D6. 
event, it was the first time they brought with them a banner to display at the game. ${ }^{3}$ Their six-foot pro-KU banner ${ }^{4}$ jokingly referenced the renaming of Mizzou Arena, ${ }^{5}$ home to the University of Missouri basketball team, with several crossed-out names and the phrase, "Call it whatever you want, it'll always be Allen Fieldhouse East," "6 reference to the hallowed basketball venue in Lawrence, Kansas.

When the four friends entered the arena, they received permission from an arena official to tape their banner to a railing so that it hung from the edge of the upper-deck. ${ }^{7}$ But before the game tipped off, an older man in an MU shirt seated near the banner learned of the sign's existence and began removing it from the rail. ${ }^{8}$ The KU student confronted the man and sought to retrieve his banner from the MU fan's grasp, but was surprised when the MU fan grabbed him by the collar of his shirt, drew him toward him, and told the KU student that he was the Chief of Police of the University of Missouri. ${ }^{9}$

Moments later, a uniformed officer arrived on the scene and ejected one of the KU fans from the arena after he asserted his free-speech rights. ${ }^{10}$ The KU students filed formal complaints with the university, which launched a twelve-week investigation ${ }^{11}$ and concluded that the police chief "acted within his bounds throughout the incident, and that

3. Phil Ameling, U. Kansas Fan Alleges Mid-Game Assault at U. Missouri, ManEAter (U. of Mo.), Mar. 11, 2005.

4. Dani Litt, Sign Prompts Tussle, U. Daily Kansan, Mar. 9, 2005, at 1A.

5. The University of Missouri's new basketball arena, Mizzou Arena, was originally named Paige Sports Arena after Paige Laurie, daughter of billionaires Bill and Nancy Laurie, who donated $\$ 25$ million toward the building campaign. College Removes Name of Wal-Mart Heiress on Arena, USA TODAY, Nov. 24, 2004, available at http://www.usatoday.com/money/industries/retail/200411-24-walmart-heiress-arena x.htm. However, in 2004, the university changed the name of its arena after it was discovered that Paige Laurie paid her college roommate approximately twenty-thousand dollars over three and a half years "to write papers and complete other assignments for her." $I d$.

6. Ameling, supra note 3 . The banner now hangs on display at The Wheel, a popular restaurant in Lawrence, Kansas, and reads in full as follows:

Norm Starter Center

WAL*MART Super Center

Paige Sports Arena

Mizzou Arena

CALL IT WHATEVER YOU WANT, IT WILL ALWAYS BE ALLEN FIELDHOUSE EAST

Always

Liz Nartowicz, Mizzou Police Chief Exonerated, U. DAILY KANSAN, June 8, 2005, at 4A.

7. Nartowicz, supra note 6 .

8. Litt, supra note 4.

9. Ameling, supra note 3.

10. Id.

11. Briefly in Sports: University OK's Handling of KU Student, supra note 2. 
safety for all fans was his motive for removing the banner."12 At the time, the University of Missouri had no policy concerning signs and banners inside Mizzou Arena. ${ }^{13}$

For years, fans across the country have attended collegiate athletic events, expressing their endless support for a favorite team and passionate opposition to their school's archrival. This form of expression, sometimes referred to as "cheering speech,"14 often is directed at "teams, players, coaches, officials, executives, administrators, or other fans.... It can be about events on the field or it can target broader social and political issues surrounding the game, the players, or sport in general." 15 Typically such speech is generated by the student section of the home team and it "supports, opposes, cheers, jeers, praises, criticizes, heckles, and even taunts" those related to the game. ${ }^{16}$ Fan expression is part of the rich tradition of collegiate athletics, and loyal school spirit is "encouraged by the teams, the players, the cheerleaders, the band, the scoreboard, and the music blaring over the sound system."17 "Cheering speech can be oral, symbolic, or written on signs, banners, clothing, and body parts. It can be in good taste or bad, clean or profane, provocative, clever, or otherwise. And it will be loud and obvious."18

Recently, universities across the country have come to realize that despite their attempts to welcome only cheers filled with spirit, passion, and good sportsmanship at collegiate athletic events, crowd noise saturated with offensive, lewd, vulgar, profane, and indecent messages has remained. Some schools have taken steps to combat offensive fan expression by regulating the size of signs and banners allowed into the game, ${ }^{19}$ while others have gone further by prohibiting signs and banners at school athletic events altogether. ${ }^{20}$

2. Nartowicz, supra note 6.

13. Id.

14. Howard M. Wasserman, Cheers, Profanity, and Free Speech, 31 J.C. \& U.L. 377, 378 (2005)

15. Id.

16. Howard M. Wasserman, Fans, Free Expression, and the Wide World of Sports, 67 U. PITT. L. REV. 525, 527-28 (2006).

17. $I d$. at 526 .

18. Id. at 528

19. See Kelley Tiffany, Cheering Speech at State University Athletic Events: How Do You Regulate Bad Spectator Sportsmanship?, 14 SPORTS LAW. J. 111, 118-19 (2007) (discussing Mississippi University's ban against fans bringing in flags and signs larger than twelve by fourteen inches).

20. Tom Knott, At UVa, Not a Sign of the Times, WASH. TIMES, Sept. 5, 2008, at C3 (discussing the University of Virginia's ban on all signs at all university athletic events in 2008). 
But to what extent can any university constitutionally impose restrictions as to the size, type, or character of a spectator's mode of expression? Are full-fledged bans the answer to silencing objectionable speech at games or should content-specific restrictions, such as a prohibition of "vulgar" language, ${ }^{21}$ be the solution? What effect will such broad policies have on student cheering speech that is not considered profane, indecent, vulgar, or derogatory, but clever, humorous, and arguably truthful, such as a sign reading, "I'm blind, I'm deaf, I wanna be a ref" 22 - or the KU student and his banner? Do collegiate sports fans have any First Amendment speech rights when they enter public university stadiums and arenas?

This Comment will examine the ability of public universities to effectively regulate student speech at collegiate athletic events in accordance with the rights guaranteed by the First Amendment. Part II of this Comment will review the prevalence of offensive fan expression in recent years and summarize the history of applicable First Amendment case law and doctrines. Part III will analyze the public forum nature of the university football stadium or basketball arena and discuss whether public universities may regulate expression within these venues. Further, this Comment will address various proposals to resolve the dispute over fan expression and offer critiques as to why such recommendations may pass First Amendment scrutiny but fail public opinion. Finally, this Comment will propose an American solution to the fan expression issue that will actively acknowledge the aims of the First Amendment-more speech, more expression. Furthermore, it will provide clear and effective options for university officials and administrators to create a collegiate athletic environment that welcomes families, students, and their messages.

21. The sign policy at the University of Missouri states:

Items that can be held by one individual, maximum 2'x3', reflect good sportsmanship, do not contain vulgar, derogatory or suggestive language and do not block the view of other ticketed patrons may be permitted. No signs, flags or banners of any size may not [sic] be affixed to the facility or any pole or stick. The Department of Athletics reserves the right to remove these items not meeting those specifications.

MUTigers.com, Football Ticket Policies and Procedures, http://mutigers.cstv.com/tickets/footblpolicies-procedures.html\#7 (last visited Mar. 1, 2009).

22. In 1998, a University of Kansas student's sign was confiscated during a KU home basketball game because the sign was deemed to be "not in the spirit of good sportsmanship." Matt Gowen, Foul Called on Sign Removal, LAWRENCE J.-WorLD, Feb. 21, 1998, available at http://www2.ljworld.com/news/1998/feb/21/foul_called_on_sign. 


\section{BACKGROUND}

\section{A. Collegiate Fan Expression Echoes and Offends}

The extent to which fan expression at collegiate sporting events has become profane, lewd, and inappropriate has recently been a topic of conversation among fans, athletic departments, and school administrators who are looking to make the experience fun and enjoyable for both students and families. Several recent examples of controversial fan expression are representative of the type that generates these conversations. During a 2004 home basketball game against Duke University, students at the University of Maryland - some wearing shirts reading "Fuck Duke"23 _ erupted into a chant of "Fuck You, J.J.!" each time Duke guard J.J. Redick approached the foul line. ${ }^{24}$ At the University of Kentucky, students chanted "Matt is gay" at Matt Walsh, a member of the visiting University of Florida basketball team. ${ }^{25}$ In 2003, students at the University of Florida taunted Maryland Terrapin guard D.J. Strawberry by referring to the drug problems of his father, former major league baseball player Darryl Strawberry. ${ }^{26}$ University of Oregon students got in on the action in 2008 during a basketball game against conference foe UCLA. Oregon fans "targeted UCLA player Kevin Love, an Oregon high school graduate," and reduced his grandmother to tears in the stands when they chanted "whores" at his family. ${ }^{27}$

Rather than using chants and cheers, fans at the Ohio State University have adorned t-shirts with the words "Ann Arbor is a Whore," a reference to their rival's hometown, ${ }^{28}$ when the university plays the University of Michigan Wolverines. Students at the University of

23. Evan Davis, Column, 'F-k Duke' Shirts Disgrace Maryland Fans, Chron. (Duke Univ.), Jan. 22, 2003, at Sports, available at http://www.dukechronicle.com/home/index.cfm?event= displayArticle\&ustory_id=8ec8482e-b6cb-4e46-94ff-ffd279bb6752.

24. Andrew Goodman, Fans Walk Fine Line with Speech: Vulgarity Raises Freedom of Speech Issue for Spectators, THE Daily Pennsylvanian, Feb. 24, 2004, at Sports, available at http:// www.dailypennsylvanian.com/media/storage/paper882/news/2004/02/24/sports/fanswalk.fine.line.with.speech-2152254.shtml.

25. Eric Hoover, Crying Foul Over Fans' Boorish Behavior: Colleges Try to Rein in Profanity at Games Without Violating Free-Speech Rights, CHrON. HigHer EDUC., Apr. 9, 2004, at A1.

26. Id.

27. Editorial, When Cheers Turn to Abuse, Colleges Need to Take Action, USA TODAY, Mar. 7, 2008 , at $12 \mathrm{~A}$.

28. Monica M. Torline, Vendors Must Sell Ann Arbor T-shirts Off OSU Grounds, LANTERN (Ohio St. U.), Nov. 16, 2000, at Campus, available at http://media.www.thelantern.com/media/ storage/paper333/news/2000/11/16/campus/vendors.must.sell.Ann.Arbor.off.OSU.grounds5154.shtml. 
Kansas for years have sported t-shirts displaying, "Muck Fizzou," 29 a jab at the school's archrival, Mizzou. In response, Missouri students in 2007 created a t-shirt displaying a picture of Lawrence, Kansas, burning in William Quantrill's raid of $1863 .^{30}$ Immediately below the picture appeared the word "Scoreboard" and a University of Missouri logo. ${ }^{31}$ Finally, using a slightly different approach, students at the University of Colorado have inserted the words "Fuck 'em Up, Fuck 'em Up, Go $\mathrm{CU}^{\prime 32}$ into one of the school's already controversial fight songs, "Rock and Roll (Part 2)." $" 33$

In reaction to what many believe is outrageous fan behavior, some schools have taken swift action to clean the stadium air. ${ }^{34}$ Before the start of the 2008 college football season, the University of Virginia put into place an all-out ban on signs and banners at the school's sporting events. ${ }^{35}$ The rule, enacted to "promote sportsmanship and a positive game day environment," 36 came almost a year after a University of Virginia student brought a sign to Scott Stadium that read "Fire Groh," referring to current University of Virginia football coach Al Groh. ${ }^{37}$ The student was threatened with ejection because his sign was not in compliance with the school's previous sign policy restricting signs of derogatory matter, signs containing profanity, or those that impeded other fans' view of the game. ${ }^{38}$ The student stated afterward, "I wasn't being obscene. I wasn't acting inappropriate. I was just holding a sign

29. Eric Weslander, Rude Shirts a Disservice to KU Spirit, Group Says, LAWRENCE J.-WoRLd, Mar. 3, 2007, at 1C.

30. George Diepenbrock, Quantrill-Themed T-Shirt Stirs Bitter Emotion, LAWRENCE J.WORLD, Nov. 14, 2007, at A1.

31. Id.

32. Buffs.tv, All Colorado Football - All the Time, http://buffs.tv/archives/2002/09/10/fck_em_ up_go_cu.html (last visited Mar. 1, 2009).

33. Gary Glitter, who won fame as a flamboyant glam rocker in the 1970s for his song "Rock and Roll (Part 2)," more popularly known as "The Hey Song," was convicted in 2006 for committing obscene acts with two underage Vietnamese girls. Nancy Armour, Why Did NFL Muzzle Gary Glitter?, B. GLOBE, Sept. 16, 2006, available at http:/www.boston.com/news/world/europe/ articles/2006/09/16/column_why_did_nfl_muzzle_gary_glitter/. In 1999, Glitter was convicted in Britain for possessing child pornography. Id. In response to Glitter's 2006 conviction, the NFL instituted a league-wide ban of the song in all of its stadiums. Id. Some universities have also banned the song from being played during games. See, e.g., Gary Bedore, Song Barred from Allen, LAWRENCE J.-WORLD, Sept. 8, 2006, at 7C (song banned at University of Kansas athletic events).

34. See When Cheers Turn to Abuse, Colleges Need to Take Action, supra note 27 (describing instances of fan verbal abuse to players, players' families, and other fans).

35. Jeff Christian, Virginia, Here's a Sign for You, MANASSA J. Messenger, Aug. 22, 2008.

36. Id.

37. Id.

38. Id. 
and expressing an opinion."39 "The ban was tweaked earlier this year to include all signs, the good and the bad" 40 - a content and viewpoint neutral position. The student section responded during a home game in 2008 when they held up plain white pieces of paper which said nothing - but yet, said everything. ${ }^{41}$

Similar restrictions have been imposed at other schools, although not to such an extent. The University of Mississippi imposed a ban on flags and banners larger than twelve by fourteen inches at its university athletic events. ${ }^{42}$ The restriction was imposed to prevent injuries from flagsticks and address complaints about such items obstructing the views of other spectators. ${ }^{43}$ In a subsequent lawsuit, brought by a student who was prohibited from displaying his confederate flag at a school football game, a U.S. District Court upheld the ban. ${ }^{44}$ The court explained that the ban's purpose of safety and control of the spectators within the stadium reflected the university's substantial interest in safe and efficient game management. ${ }^{45}$

\section{B. A Brief Overview of the Freedom of Speech}

A person's ability to express himself or herself freely without fear of persecution is one of the cornerstones to the First Amendment of the U.S. Constitution. It directly prohibits Congress from making any law "abridging the freedom of speech." 46 Initially, however, the protections of the First Amendment were limited, understood to be a strict restriction only on the federal government's ability to regulate individual speech. ${ }^{47}$ This left the states free to regulate expression to the extent that their respective state constitutions would permit.

39. Brian McNeill, Signs Lead to Trouble: Game Day Commentary Spurs Speech Debate, Clover Herald, Sept. 13, 2007.

40. Knott, supra note 20.

41. Paul Kimbrough, UVA Dropped Ball on Sign Ban, Reflector, Sept. 12, 2008, available at http://media.www.reflector-online.com/media/storage/paper938/news/2008/09/12/Sports/UvaDropped.Ball.On.Sign.Ban-3427800.shtml.

42. Barrett v. Khayat, No. CIV.A. 397CV211BA, 1999 WL 33537194, at *1 (N.D. Miss. Nov. 12, 1999).

43. Id.

44. Id. at $* 1, * 4$

45. Id. at *4.

46. U.S. CONST. amend. I.

47. See Barron v. Baltimore, 32 U.S. 243, 247-48, 250 (1833) (holding that the commands of the Bill of Rights, specifically the Fifth Amendment's takings clause, apply only to the federal government and place no restriction on the state governments). 
However, this view slowly changed following the ratification of the Fourteenth Amendment, which states that "[n]o State shall make or enforce any law which shall abridge the privileges or immunities of citizens of the United States; nor shall any State deprive any person of life, liberty, or property, without due process of law." 48 A series of cases following the ratification of the Fourteenth Amendment began to incorporate portions of the Bill of Rights, including the First Amendment, through the Due Process Clause, making them enforceable against the states. The Court in Rochin $v$. California explained that "[d]ue process of law is a summarized constitutional guarantee of respect for those personal immunities which Mr. Justice Cardozo twice wrote for the Court, are 'so rooted in the traditions and conscience of our people as to be ranked as fundamental." $" 49$

Despite this broad application of the First Amendment to both state and federal government, the guarantee of free speech is still not absolute. ${ }^{50}$ The Court over time has developed an informal hierarchy of protected speech, ranging from the complete protection of a man whose jacket read "Fuck the Draft," ${ }^{, 51}$ to prohibiting another man from telling a police officer he is "a God damned racketeer" and "a damned Fascist.",52 In the middle lay all other forms of speech that to some degree may be regulated to the extent that such regulation is based upon important governmental interests. It seems, however, the Court will always favor a "market place of ideas" approach-where more speech is better than less

48. U.S. Const. amend. XIV, $\S 1$.

49. Rochin v. California, 342 U.S. 165, 169 (1952) (quoting Snyder v. Massachusetts, 291 U.S. 97, 105 (1934)).

50. See Pope v. Illinois, 481 U.S. 497, 500-01 (1987) (holding that the First Amendment only protects works where a reasonable person would find the material, as a whole, has "serious literary, artistic, political, or scientific value"); Brandenburg v. Ohio, 395 U.S. 444, 447 (1969) (holding that the states can forbid speech that is intended to incite imminent lawless action and is "likely to incite or produce such action"); New York Times Co. v. Sullivan, 376 U.S. 254, 279-80 (1964) (holding that defamation based on actual malice receives no First Amendment protection); Chaplinsky v. New Hampshire, 315 U.S. 568, 574 (1942) (holding that fighting words receive no First Amendment protection).

51. Cohen v. California, 403 U.S. 15, 16-17, 19-21 (1971).

52. Chaplinsky, 315 U.S. at 574 (holding that fighting words receive no First Amendment protection). 
because we are all best served by a vigorous and open debate. ${ }^{53}$ In Cohen v. California, Justice Harlan wrote:

The constitutional right of free expression is powerful medicine in a society as diverse and populous as ours. It is designed and intended to remove government restraints from the arena of public discussion, putting the decision ... into the hands of each of us, in the hope that use of such freedom will ultimately produce a more capable citizenry and more perfect polity and in the belief that no other approach would comport with the premise of individual dignity and choice upon which our political system rests. ${ }^{54}$

\section{Unprotected Speech: At the Stadium and on the Street}

At the bottom of the free speech hierarchy are the various forms of expression that the Court has determined receive absolutely no protection because they lack social value and have little redeeming quality. ${ }^{55}$ Within this category of speech, the Court has held that defamation, obscenity, fighting words, and the illegal advocacy of imminent lawless action will receive zero protection under the First Amendment. ${ }^{56}$ However, the more challenging determination for the Court has been determining whether various forms of speech fall within one of these categories.

53. See New York Times, 376 U.S. at 271-72 (““To persuade others to his own point of view, the pleader, as we know, at times, resorts to exaggeration, to vilification of men who have been, or are, prominent in church or state, and even to false statement. But the people of this nation have ordained in the light of history, that, in spite of the probability of excesses and abuses, these liberties are, in the long view, essential to enlightened opinion and right conduct on the part of the citizens of a democracy.' ... [E]rroneous statement is inevitable in free debate, and ... it must be protected if the freedoms of expression are to have the 'breathing space' that they 'need ... to survive' ...." (quoting Cantwell v. Connecticut, 310 U.S. 296, 310 (1940))).

54. Cohen, 403 U.S. at 24.

55. See Gertz v. Robert Welch Inc., 418 U.S. 323, 349 (1974) (defamatory speech about private individuals); Miller v. California, 413 U.S. 15, 26 (1973) (obscenity); Brandenburg, 395 U.S. at 447 (speech that incites imminent lawless action); New York Times, 376 U.S. at 279-80 (defamatory speech made with actual malice); Chaplinsky, 315 U.S. at 574 (fighting words).

56. Beauharnais v. Illinois, 343 U.S. 250, 255-57 (1952) ("There are certain well-defined and narrowly limited classes of speech, the prevention and punishment of which has never been thought to raise any Constitutional problem. These include the lewd and obscene, the profane, the libelous, and the insulting or 'fighting' words... [i]t has been well observed that such utterances are no essential part of any exposition of ideas, and are of such slight social value as a step to truth that any benefit that may be derived from them is clearly outweighed by the social interest in order and morality."). 


\section{a. Defamation of Public and Private Figures}

While different standards exist for establishing defamation of public versus private figures, ${ }^{57}$ the basic premise remains the same: the act of harming the reputation of another by making a false statement to a third party will not receive protection by the Court. ${ }^{58}$ For example, the Court in New York Times Co. v. Sullivan noted that unpleasant attacks on the government and its officials are important aspects of political speech which deserve protection, but when a speaker engages in actual malice against another, the government is able to regulate. ${ }^{59}$ But the Court did not go so far as to require the absolute truth from speakers either, allowing room for mistakes of fact to enter the arena of public dialogue. ${ }^{60}$ This stance illustrates the Court's belief in and desire to promote a rich marketplace of ideas. ${ }^{61}$

It may be possible for fan expression to be characterized as defamation if a specific player, coach, or high-level administrator is the target of such expression. However, most of the cheering speech at issue relates to offensive and indecent language rather than harming the reputation of a specific individual. But, because defamation is not recognized as a protected form of speech, public universities are free to ban such speech at school athletic events.

\section{b. Obscene Materials}

Obscenity, a form of speech considered socially taboo as a result of the depiction of sexually explicit material, also will not receive protection under the First Amendment. ${ }^{62}$ The Court has recognized that states have a significant interest in prohibiting the dissemination of obscene material, which carries with it a significant danger of offending the sensibilities of unwilling recipients or of exposure to children. ${ }^{63}$

57. See New York Times, 376 U.S. at 279-80 (requiring a showing of actual malice); Gertz, 418 U.S. at $345-46$ (holding that states should retain the ability to determine remedies for "defamatory falsehood[s] injurious to the reputation of a private individual").

58. See Black's Law Dictionary 448 (8th ed. 1999); see also New York Times, 376 U.S. at 283; Gertz, 418 U.S. at 345-46.

59. New York Times, 376 U.S. at 283.

60. Id. at 279 .

61. See Gertz, 418 U.S. at 341 ("The First Amendment requires that we protect some falsehood in order to protect speech that matters.").

62. See Miller v. California, 413 U.S. 15, 23 (1973).

63. Id. at 18-19 ("This Court has recognized that the States have a legitimate interest in prohibiting dissemination or exhibition of obscene material when the mode of dissemination carries with it a significant danger of offending the sensibilities of unwilling recipients or of exposure to 
While the general prohibition on obscenity seems clear-cut, the Court has struggled in determining what standards should be used to measure obscenity in the community. That standard was clarified by the Court in Miller v. California. ${ }^{64}$ The Court adopted the following threepart test for determining obscenity: (1) a reasonable person applying community standards thinks the work applies to a prurient interest; (2) the work depicts sexual conduct (defined by state law); and (3) the work lacks serious literary, artistic, political, or scientific value. ${ }^{65}$

To the extent fan expression at collegiate sporting events reaches the level of obscenity, universities remain free to impose strict regulations prohibiting such content inside their stadiums. But college sports fans are bringing profane and offensive signs and banners into games, not images of pornography. Fans are chanting and yelling indecent and vulgar remarks in unison, not engaging in sexual conduct in the stands. Thus, the recognized prohibition of obscenity hardly seems relevant in college stadiums and arenas.

\section{c. Fighting Words}

Another form of speech the Court has held receives no protection is fighting words - "those which by their very utterance inflict injury or tend to incite an immediate breach of the peace." 66 This form of expression includes "those personally abusive epithets which, when addressed to the ordinary citizen, are, as a matter of common knowledge, inherently likely to provoke violent reaction." ${ }^{67}$ In Chaplinsky v. New Hampshire, the defendant, a Jehovah's Witness, was convicted of violating a state law criminalizing the use of offensive speech when he called a police officer "a God damned racketeer" and "a damned Fascist." "The Chaplinsky court held that the test of fighting words "is not to be defined in terms of what a particular addressee thinks[, but] what men of common intelligence would understand would be words likely to cause an average addressee to fight."

While initially this doctrine is tempting for proponents of regulation of fan expression to use in support of their position, it is important to note that since Chaplinsky was decided in 1942, the Court has gone

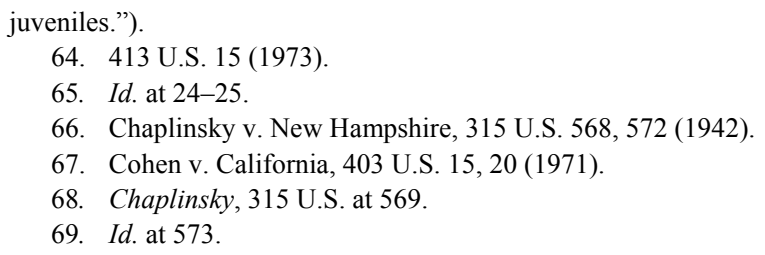


sixty-seven years without basing a decision on the "fighting words" doctrine. ${ }^{70}$ During that time, the Court has chosen to construe the doctrine narrowly whenever the occasion to address it has arisen. ${ }^{71}$

\section{d. Illegal Advocacy}

First Amendment protections will also not be overcome if an individual simply advocates violating the law. ${ }^{72}$ As the Court explained in Brandenburg v. Ohio, such speech will remain lawful unless (1) the advocacy is intentionally directed to inciting imminent lawless action and (2) the speaker's actions are likely to produce such action. ${ }^{73}$ In Brandenburg, the defendant was prosecuted for advocating the commission of various crimes. ${ }^{74}$ A videotape recording showed him leading $\mathrm{Ku}$ Klux Klan members and suggesting an overthrow of the government. ${ }^{75}$ The Court held the statute in question, which purported to forbid and punish mere advocacy of a defined type of action, to be unconstitutional. ${ }^{76}$

It is unlikely that fan expression at college sporting events will ever be considered under this category of speech. To the extent rowdy student sections begin unison chants intentionally directed at inciting imminent lawless action, and which are also likely to produce such action, the university may take action. But this scenario is not likely to occur, except possibly when a student begins advocating for the student section to tear down the goal posts following a football game.

\section{Speech Subject to Government Regulation}

At the top of the free speech hierarchy-receiving ultimate protection from the Supreme Court-is political speech; a form of expression that Justice Cardozo would likely argue is "rooted in the traditions and conscience of [the] people." "77 But over time, even protected forms of speech have been subject to First Amendment scrutiny, especially when (1) such expression becomes intertwined with

70. Stephen R. McAllister, Funeral Picketing Laws and Free Speech, 55 U. KAN. L. REV. 575, 591 (2007).

71. Id.

72. See Brandenburg v. Ohio, 395 U.S. 444, 449 (1969).

73. Id. at 447.

74. Id. at $444-45$.

75. Id. at $445-47$.

76. Id. at 449 .

77. See, e.g., Snyder v. Massachusetts, 291 U.S. 97, 105 (1934). 
offensive language and conduct, (2) the listeners are a captive audience, or (3) the speakers are students in a school classroom.

a. Offensive Words and Conduct

The Court in Cohen v. California recognized that offensive words and profanity are "necessary side effects of the broader enduring values which the process of open debate permits us to achieve.... Surely the State has no right to cleanse public debate to the point where it is grammatically palatable to the most squeamish among us." ${ }^{, 78}$ Furthermore, the Court noted that freedom of speech is "powerful medicine," 79 and words are often chosen as much for their emotional force as their cognitive strength. ${ }^{80}$ The Court has indicated that it does not want to decide the value and relative emotive function of all profane words for society because they "may often be the more important element of the overall message sought to be communicated." 81

In Cohen, the defendant walked into a county courthouse wearing a jacket bearing the words "Fuck the Draft" as a means of informing the public of his feelings against the Vietnam War. ${ }^{82}$ People were present throughout the corridor, including children, when the defendant entered, but neither the defendant nor anyone in the public committed or threatened to commit any act of violence. ${ }^{83}$ In fact, there was no evidence the defendant "uttered any sound prior to his arrest." 84 The Court, in reversing the defendant's breach of the peace conviction, differentiated the speaker's expression in the courthouse from the "fighting words" speech found in Chaplinsky by focusing on the reaction of the receiver of the speech. ${ }^{85}$ "No individual actually or likely to be present could reasonably have regarded the words on appellant's jacket as a direct personal insult." $" 86$

The interaction between speech and conduct can pose an even more difficult question for the Court. While sometimes the distinction between the two is clear for appropriate and lawful governmental

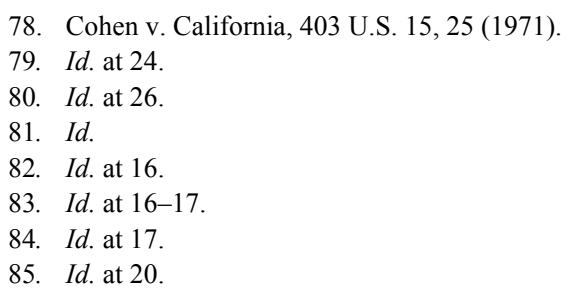


regulation, ${ }^{87}$ in other instances they seem to blend into one message. This combination, referred to as "symbolic speech" by the defendant in United States v. O'Brien, ${ }^{88}$ requires special consideration. To the extent such speech and non-speech elements are combined in the same course of conduct, "a sufficiently important governmental interest in regulating the non-speech element can justify incidental limitations on First Amendment freedoms." ${ }^{\prime 89}$

In O'Brien, the defendants publicly burned their Selective Service draft cards on the steps of a Boston courthouse in an effort to influence others to adopt their anti-war beliefs. ${ }^{90}$ Having been charged with destroying their draft cards, ${ }^{91}$ the defendants argued that the act of burning their draft certificates was symbolic speech, a protected mode of communication by conduct under the First Amendment. ${ }^{92}$ But the Court held that "government regulation is sufficiently justified if it . . furthers an important or substantial governmental interest; if the governmental interest is unrelated to the suppression of free expression; and if the incidental restriction on alleged First Amendment freedoms is no greater than is essential to the furtherance of that interest." $" 93$ It explained that Congress had a legitimate and substantial interest in preventing the destruction of the draft certificates because the "[n]ation has a vital interest in having a system for raising armies that functions with maximum efficiency and is capable of easily and quickly responding to continually changing circumstances. $" 94$

Similarly, in Texas v. Johnson, the defendant was convicted of desecrating a venerated object after he doused an American flag with kerosene and set it on fire outside of city hall in Dallas, Texas, as part of a group protest against the policies of the Reagan administration. ${ }^{95}$ In holding the state law unconstitutional for being content and viewpoint based, the Court reiterated its "bedrock principle" underlying the First Amendment by stating that "government may not prohibit the expression of an idea simply because society finds the idea itself offensive or

87. See, e.g., Clark v. Cmty. for Creative Non-Violence, 468 U.S. 288, 293 (1984) (holding that the National Park Service's regulation prohibiting camping on the National Mall did not violate the First Amendment).

88. 391 U.S. 367,376 (1968).

89. Id.

90. Id. at 369-70.

91. Id.

92. Id. at 376 .

93. Id. at 377 .

94. Id. at 381 .

95. Texas v. Johnson, 491 U.S. 397, 399-400 (1989). 
disagreeable." $" 96$ The Court refused to permit certain symbols to be used to communicate only a limited set of messages and instead urged that the appropriate remedy is more speech - to protest the protestors rather than enforce silence. ${ }^{97}$ "[The Court] can imagine no more appropriate response to burning a flag than waving one's own, no better way to counter a flag burner's message than by saluting the flag that burns . . .."98

\section{b. Captive Audience}

The captive audience doctrine represents the notion that speech may be restricted when the listener cannot, as a practical matter, escape from the intrusive speech of another. ${ }^{99}$ In applying the principle, the Court must be careful to balance free expression with its interest in protecting those who essentially become prisoners of potentially rude, indecent, and profane expression. The Court has recognized, for example, its significant interest in protecting an individual's right to privacy within his or her home, and that this interest plainly outweighs the First Amendment rights of an intruder. ${ }^{100}$ Justice O'Connor, in her Frisby $v$. Schultz opinion, wrote:

One important aspect of residential privacy is protection of the unwilling listener. Although in many locations, we expect individuals to simply avoid speech they do not want to hear, the home is different. ... Instead, a special benefit of the privacy all citizens enjoy within their own walls ... is an ability to avoid intrusions. Thus, we have repeatedly held that individuals are not required to welcome

96. Id. at 414

97. Id. at $419-20$.

98. Id. at 420 .

99. See Black's Law Dictionary 224 (8th ed. 1999); see also Frisby v. Schultz, 487 U.S. 474, 484-85 (1988) (holding that individuals are not required to welcome unwanted speech into their homes); Erznoznik v. Jacksonville, 422 U.S. 205, 210-11 (1975) (holding that government cannot decide which types of otherwise protected speech are sufficiently offensive to require protection for those unwilling viewers standing outside of a drive-in movie theater with a view of the screen depicting scenes of female nudity); Lehman v. City of Shaker Heights, 418 U.S. 298, 304 (1974) (holding that a city may prohibit political advertisements from being displayed within its transit system because the passengers of the system are a captive audience).

100. See Frisby v. Schultz, 487 U.S. 474, 484-85 (1988) (“One important aspect of residential privacy is protection of the unwilling listener.”); FCC v. Pacifica Found., 438 U.S. 726, 748 (1978) ("Patently offensive, indecent material presented over the airwaves confronts the citizen, not only in public, but also in the privacy of the home, where the individual's right to be left alone plainly outweighs the First Amendment rights of an intruder." (citing Rowan v. Post Office Dep't, 397 U.S. $728(1970)))$. 
unwanted speech into their own homes and that the government may protect this freedom. ${ }^{101}$

Beyond the confines of one's dwelling, the Court has remained diligent in protecting the unwilling ears of captive listeners and viewers. In Lehman v. City of Shaker Heights, the Court deemed passengers of a city transit system to be a captive audience after a politician sought to promote his candidacy for public office by utilizing advertising space in the city's streetcars. ${ }^{102}$ In upholding the city's prohibition on political advertisements in its streetcars, the Court stated that "the nature of the forum and the conflicting interests involved have remained important in determining the degree of protection afforded by the Amendment to the speech in question."103 The Court noted that "the city is engaged in commerce.... [A] city transit system has discretion to develop and make reasonable choices concerning the type of advertising that may be displayed in its vehicles."104 It reasoned that to allow political propaganda would leave "lurking doubts about favoritism" and result in "sticky administrative problems ... in parceling out limited space to eager politicians." 105

However, the Court in Cohen considered application of the captive audience doctrine to whether the defendant's "Fuck the Draft" message subjected unwilling viewers to his profane message such that they would be unable to escape from its offensive nature. ${ }^{106}$ The argument was made that the defendant's "mode of expression was thrust upon unwilling or unsuspecting viewers" and thus the State should act "to protect the sensitive from otherwise unavoidable exposure to [the defendant's] crude form of protest."107 The Court explained, however, that "the mere presumed presence of unwitting listeners or viewers does not serve automatically to justify curtailing all speech capable of giving offense.... Those in the Los Angeles courthouse could effectively avoid further bombardment of their sensibilities simply by averting their eyes." 108

This same rationale was followed by the Court in Erznoznik v. City of Jacksonville, where the manager of a drive-in movie theater was

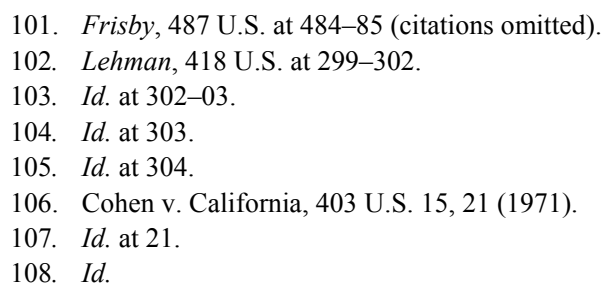


charged with violating a municipal ordinance for showing a motion picture depicting female nudity because the screen was visible from public streets. ${ }^{109}$ In holding the municipal ordinance to be invalid, the Court explained that "the Constitution does not permit government to decide which types of otherwise protected speech are sufficiently offensive to require protection for the unwilling listener or viewer. Rather, ... the burden normally falls upon the viewer to 'avoid further bombardment of [his] sensibilities simply by averting [his] eyes.","110

\section{c. Student Speech at the Schoolhouse and on Campus}

The issue of whether free speech and expression rights are available to those within a State's public school system was explored in Tinker $v$. Des Moines Independent Community School District, where the Supreme Court recognized that neither "students [n]or teachers shed their constitutional rights to freedom of speech or expression at the schoolhouse gate."111 In Tinker, a group of high school students was sent home from school because they wore black armbands to class in an effort to "publicize their objections to the hostilities in Vietnam."112 The students' actions were in violation of a school policy prohibiting the display of such armbands at school. ${ }^{113}$

In evaluating the school's regulation in Tinker, the Court noted that for a state sponsored school to justify a prohibition of expression of opinion, "it must be able to show that its action was caused by something more than a mere desire to avoid the discomfort and unpleasantness that always accompany an unpopular viewpoint." ${ }^{\text {114 }}$ The Court continued:

School officials do not possess absolute authority over their students. Students in school as well as out of school are "persons" under our Constitution. They are possessed of fundamental rights which the State must respect, just as they themselves must respect their obligations to the State. ... [Students] may not be confined to the expression of those sentiments that are officially approved. ${ }^{115}$

\footnotetext{
109. Erznoznik v. City of Jacksonville, 422 U.S. 205, 206 (1975).

110. Id. at 210-11 (alteration in original) (quoting Cohen, 403 U.S. at 21).

111. Tinker v. Des Moines Indep. Cmty. Sch. Dist., 393 U.S. 503, 506 (1969).

112. Id. at 504 .

113. Id.

114. Id. at 509 .

115. Id. at 511 .
} 
The Court held that a student may express his or her opinions "in the cafeteria, or on the playing field, or on the campus during the authorized hours," so long as the student "does so without "materially and substantially interfer[ing] with the requirements of appropriate discipline in the operation of the school' and without colliding with the rights of others." 116 If a student disrupts class-work or substantially invades the rights of others, the student is not "immunized by the constitutional guarantee of freedom of speech." 117

But in Bethel School District No. 403 v. Fraser, the Court limited the right of student expression in public schools. ${ }^{118}$ In Fraser, a high school student delivered a speech to a school assembly in which he referred to a candidate for student elective office "in terms of an elaborate, graphic, and explicit sexual metaphor."119 Afterwards, the student was informed that his speech was in violation of a school policy prohibiting the use of obscene language in the school and that he was suspended. ${ }^{120}$ The Court contrasted this conduct from that in Tinker, stating that the penalties imposed in Fraser were unrelated to any political viewpoint:

The First Amendment does not prevent the school officials from determining that to permit a vulgar and lewd speech... would undermine the school's basic educational mission. A high school assembly or classroom is no place for a sexually explicit monologue directed towards an unsuspecting audience of teenage students. Accordingly, it was perfectly appropriate for the school to dissociate itself to make the point to the pupils that vulgar speech and lewd conduct is wholly inconsistent with the "fundamental values" of public school education.

But to what extent do the holdings in Tinker and Fraser apply to public schools of higher education and the regulation of speech on a college campus? The Court addressed this issue in its Papish v. Board of Curators of the University of Missouri ${ }^{122}$ opinion. In Papish, a university graduate student was expelled for distributing a newspaper on campus that contained a cartoon depiction of "policemen raping the Statue of

116. Id. at 512-13 (alteration in original) (quoting Burnside v. Byars, 363 F.2d 744, 749 (5th Cir. 1966)).

117. Id.

118. Bethel Sch. Dist. No. 403 v. Fraser, 478 U.S. 675, 677-78 (1986).

119. Id.

120. Id. at 678 .

121. Id. at $685-86$.

122. 410 U.S. 667 (1973). 
Liberty and the Goddess of Justice." 123 The caption under the image read, "“With Liberty and Justice for All.,"124 The paper also contained an article entitled "M[other] F[ucker] Acquitted," in reference to the trial "of a New York City youth who was a member of an organization known as 'Up Against the Wall, M[other] F[ucker]." ${ }^{25}$ In protecting the student's speech, the Court noted "that the mere dissemination of ideas - no matter how offensive to good taste - on a state university campus may not be shut off in the name alone of "conventions of decency.'",126

The Court's per curiam opinion in Papish relied on its prior decision in Healy v. James, ${ }^{127}$ a case where the Court held that "state colleges and universities are not enclaves immune from the sweep of the First Amendment." 128 In Healy, a group of students at a state college sought official recognition from the school of their student "leftist" organization, ${ }^{129}$ but the President of the school declined the group's application - a decision which would deprive the members of the opportunity to place announcements in the school newspaper or on school bulletin boards, and of the use of campus facilities for holding meetings - because he thought the "organization's philosophy was antithetical to the school's policies." dismissal of the action, the Court explained:

[T]his Court has long recognized "the need for affirming the comprehensive authority of the States and of school officials, consistent with fundamental constitutional safeguards, to prescribe and control conduct in the schools." Yet, the precedents of this Court leave no room for the view that... First Amendment protections should apply with less force on college campuses than in the community at large. Quite to the contrary, "[t]he vigilant protections of constitutional freedoms is nowhere more vital than in the community of American schools." The college classroom ... is peculiarly the "'marketplace of ideas," and we break no new constitutional ground in reaffirming this Nation's dedication to safeguarding academic freedom. ${ }^{131}$

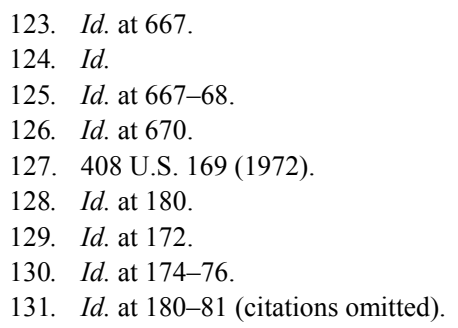


Since the Court has recognized that the guarantees of the First Amendment apply to students in university classes and on college campuses, does it seem logical that those same protections should extend to the university football stadium and basketball arena? How similar must the university classrooms of the weekday be to the student sections on the weekends? To what extent are the educational missions of the universities active when classes are in recess?

\section{Time, Place, and Manner: The Public Forum Analysis}

Whether the right to free speech granted by the First Amendment reaches sports fans in the bleachers at collegiate sports venues initially will depend on the ownership of the sports venue. For private schools like Notre Dame, Harvard, and Duke, the regulation of speech by school administrators can be accomplished with greater ease than their public school counterparts. This is because the facilities of the Fighting Irish, the Crimson, and the Blue Devils are not state property, but privately owned. Thus, the private schools can regulate the expression of fans with greater freedom as private owners. ${ }^{132}$ In contrast, the stadiums and arenas at public universities are bound by the commands of the Constitution through the Due Process Clause of the Fourteenth Amendment. ${ }^{133}$

But, it is insufficient that government simply "owns the property [at issue] - rather, the test is whether the property is of a type that has traditionally been used as a forum for expression." "134 The existence of a right to access public property and limits upon such a right must be evaluated by differing standards, "depending on the character of the property at issue." 135 The Supreme Court in Perry Education Ass' $n v$. Perry Local Educators' Ass'n identified three classifications of governmental property ${ }^{136}$ and described the extent to which a state may regulate speech for each designation.

132. See Louis M. Benedict \& John D. McMillen, Free Expression Versus Prohibited Speech: The First Amendment and College Student Sports Fans, 15 J. LEGAL ASPECTS SPORT 5, 15 (2005) ("[S]tate colleges and universities are subject to the Free Speech Clause of the First Amendment.").

133. See Se. Promotions, Ltd. v. Conrad, 420 U.S. 546, 547 (1975) ("[T]he Fourteenth Amendment has made applicable to the States the First Amendment's guarantee of free speech.").

134. McAllister, supra note 70, at 595.

135. Perry Educ. Ass'n v. Perry Local Educators' Ass'n, 460 U.S. 37, 44 (1983).

136. Id. at 45-46. 


\section{Traditional Public Fora}

The Court in Perry noted that on one side of the public fora spectrum are the streets, sidewalks, ${ }^{137}$ and parks, "which 'have immemorially been held in trust for the use of the public and ... have been used for purposes of assembly, communicating thoughts between citizens, and discussing public questions.",138 This first category represents the "quintessential public forum[]," a place "which by long tradition or by government fiat [has] been devoted to assembly and debate." 139

However, despite the historical preservation of speech, these traditional public fora are not immune from regulation. As Justice Butler wrote in the Court's opinion of Hague v. Committee for Industrial Organization:

The privilege of a citizen of the United States to use the streets and parks for communication of views ... may be regulated in the interest of all ... and must be exercised in subordination to the general comfort and convenience, and in consonance with peace and good order; but it must not, in the guise of regulation, be abridged or denied. ${ }^{140}$

Content-based restrictions, including an absolute prohibition on a particular type of expression, by the state must survive strict scrutiny: the state "must show that [enforcement of] its regulation is necessary to serve a compelling state interest and that [the regulation] is narrowly [tailored] to achieve that [interest]." 141 Furthermore, the state may also enforce content-neutral time, place, and manner restrictions on expression that "are narrowly tailored to serve a significant governmental interest, and leave open ample alternative channels of communication." 142

\section{Limited Public Fora}

The second forum classification, limited public fora, "consists of public property which the state has opened for use by the public as a

137. See United States v. Grace, 461 U.S. 171, 183-84 (1983) (holding that the government cannot prohibit the display of "signs, banners or devices on the public sidewalks surrounding the [Supreme Court] building," but may subject the sidewalks to reasonable time, place, and manner restrictions).

138. Perry, 460 U.S. at 45 .

139. Id.

140. Hague v. Comm. for Indust. Org., 307 U.S. 496, 515-16 (1939).

141. Perry, 460 U.S. at 45 .

142. Id. 
place for expressive activity," ${ }^{143}$ but which has not traditionally been an area open for expression. In this forum, the state is not required to allow individuals to engage in expression because it "retains the option of closing the forum entirely, rather than adopting valid time, place, and manner regulations." 144 An example of this forum category is public school facilities, which in the evening and on weekends are open for groups to assemble, but during the weekday are closed to public expression for the education of children. ${ }^{145}$

A state is not required to retain the open character of these limited or designated public forums, but as long as it does, "it is bound by the same standards that apply in a traditional public forum." "146 Thus, "the government violates the First Amendment when it denies access to a speaker solely to suppress the point of view he espouses on an otherwise includible subject.",147 The state may enforce content-neutral time, place, and manner restrictions on expression that are "narrowly tailored to serve a significant governmental interest, and leave open ample alternative channels of communication."148

\section{Nonpublic Fora}

The third classification is the non-public forum-public property that is not by tradition a forum for public communication, ${ }^{149}$ such as government offices, airports, ${ }^{150}$ or city-operated transit vehicles. ${ }^{151}$ It is here that a state may reserve the forum for its intended purposes and restrict public expression because it, like a private owner of property, has the " "power to preserve the property under its control for the use to

\footnotetext{
143. Id.

144. McAllister, supra note 70 , at 596 .

145. See Lamb's Chapel v. Ctr. Moriches Union Free Sch. Dist., 508 U.S. 384, 386-88 (1993) (holding that a school district's refusal to grant a church group access to school premises solely because the group wanted to show a religious film violated the First Amendment); Good News Club v. Milford Cent. Sch., 533 U.S. 98, 102-03 (2001) (holding that a "school's exclusion of a Christian children's club from meeting after hours at school based on its religious nature was unconstitutional viewpoint discrimination")

146. Perry, 460 U.S. at 46.

147. Lamb's Chapel, 508 U.S. at 394 (quoting Cornelius v. NAACP Legal Def. Fund, Inc., 473 U.S. 788, $806(1985))$.

148. Perry, 460 U.S. at 45.

149. Id. at 46 .

150. See Int'l Soc'y for Krishna Consciousness v. Lee, 505 U.S. 672, 672, 680-81 (1992) (holding that an airport terminal is a nonpublic forum for First Amendment purposes).

151. See Lehman v. City of Shaker Heights, 418 U.S. 298, 298, 304 (1974) (holding that a city's transit system is a nonpublic forum for First Amendment purposes).
} 
which it is lawfully dedicated." "152 The Perry court noted, "[w]e have recognized that the 'First Amendment does not guarantee access to property simply because it is owned or controlled by the government." 153 Thus, in addition to time, place, and manner restrictions in these non-public fora, the challenged regulation need only be reasonable, as long as it is not an effort to suppress speech that the government opposes. ${ }^{154}$

In Perry, the Court determined that a school's internal mail facilities fell under the third classification as a non-public forum. ${ }^{155}$ Because the mail system was not open to the public and permission for access to the system was not provided indiscriminately by the school principal, selective access to the mail system for outside organizations did not transform the government property into a public forum. ${ }^{156}$

\section{REgUlating FAN EXPRESSION AT COLLEGIATE SPORTS VENUES}

\section{A. Collegiate Sports Venues: Limited Public Fora}

The question now becomes, which classification ought to apply to a collegiate sports venue? To make this determination, it is important to consider first, who owns the property and second, if owned by the government, the purposes to which these spaces have traditionally been devoted. Because this Comment focuses explicitly on the regulation of sports venues at public colleges and universities, it is already established that the stadiums and arenas at issue are governmental property of the state in which they are located.

The question then becomes, for what purposes have collegiate sports venues traditionally been devoted with regard to expression? Clearly, the primary purpose of such venues is to offer a facility suitable to host athletic events for both teams to compete, but also for the general public to attend, observe, and participate in the event through expression. However, access to these venues is not completely open to the public like a sidewalk or town square might be. Rather, football stadiums are packed with screaming fanatics on only a handful of Saturdays each

152. Perry, 460 U.S. at 46 (quoting U.S. Postal Serv. v. Council of Greenburgh Civic Ass'n, 453 U.S. 114, $130(1981))$.

153. Id. (quoting U.S. Postal Serv., 453 U.S. at 129).

154. Int'l Soc'y for Krishna Consciousness, 505 U.S. at 679.

155. Perry, 460 U.S. at 46.

156. Id. at 47 . 
season; throughout the vast majority of the rest of the year, public access is restricted.

For this reason, it is quite likely that collegiate sports venues do not rise to the level of the open public forum such as a street, sidewalk, or public park. Stadiums and arenas are made available to public access only for limited amounts of time and for limited purposes. Furthermore, fans must purchase a ticket in order to gain admission to the venue. Stadiums also have not traditionally been a location which has " "immemorially been held in trust for the use of the public... for purposes of assembly, communicating thoughts between citizens, and discussing public questions. ""157

However, stadiums and arenas are clearly fora for expressive activity. Before, during, and after games, those in attendance routinely participate in university-sponsored rituals and traditions, often led by the cheerleaders, the marching band, or scoreboard operators, who encourage thousands to clap, chant, sing, and yell together in unison. At Texas A\&M University, this type of school spirit is such a force that the fans at Kyle Field have come to be known as the "Twelfth Man"158 for their influence in creating a hostile playing environment for opposing teams. Additionally, fans frequently take it upon themselves to create cheers and chants at athletic events to help motivate their team. Student sections are notorious for their creativity and indecency, but they are also the source of commonplace yells across the country such as "De-Fense," "Over-rated," and "Air-ball."

Because universities intentionally invite fans to fill their stadiums with noise, spirit, and similar expressive activity, and have traditionally done so, collegiate sports venues must be considered limited public fora for First Amendment purposes. ${ }^{159}$ Thus, so long as the government keeps sports stadiums and arenas open for cheering speech, the government may impose restrictions on speech that are content-neutral

157. Id. at 45 (quoting Hague v. Comm. for Indus. Org., 307 U.S. 496, 515 (1989)).

158. Texas A\&M University Traditions Council, http://traditions.tamu.edu/traditions (last visited Mar. 13, 2009) ("The entire student body at A\&M is the Twelfth Man, and they stand during the entire game to show their support.... The 12th Man tradition exists also in musical form; the student body sings 'The Twelfth Man' after each game in which the Aggies are outscored.").

159. See Clay Calvert \& Robert D. Richards, Fans and the First Amendment: Cheering and Jeering in College Sports, 4 VA. SPORTS \& ENT. L.J. 1, 15 (2004) ("[A] venue dedicated to speech activities, indeed may result in the finding of a limited public forum. These facilities are typically held open to expressive activities, arguably creating the tradition of speech...."); Wasserman, supra note 14, at 386-87 ("The stadium grandstand should be understood as a limited designated public forum for fans and for cheering speech."); Wasserman, supra note 16, at 532 ("[T]he bleachers form a designated public forum for fans and for cheering speech.”). 
and narrowly tailored to further significant governmental interests, but it must "leave open ample alternative channels of communication."160

Some scholars argue, however, that despite the rowdy, boisterous, and noisy environment present inside a collegiate sports venue, such locations are non-public fora, subject to reasonable government regulation. ${ }^{161}$ They argue that "state owned or operated property does not become a public forum simply because the public is allowed to come and go at will." 162 University facilities are dedicated for the educational purposes of students and thus restrictions within the stadiums ought to be similar to those imposed within the classrooms across the street. ${ }^{163}$ In further support of this position, they have provided the following rationale:

[T] he underlying purpose of college athletics is to provide an extracurricular educational experience for student athletes. The educational mission of the school is advanced by encouraging sportsmanlike behavior for the student athletes and fans alike. Thus, it is clearly reasonable to have regulations that attempt to maintain a civil environment for college athletics from both a participant and fan perspective. ${ }^{164}$

While university facilities are dedicated for the educational purposes of students, and schools ought to have an obligation to promote sportsmanship among those who attend their institution, government restrictions must not discriminate on the basis of viewpoint. ${ }^{165}$ As explained below, schools can encourage, but they cannot force; they can attempt, but they cannot command compliance with what the school believes ought to be appropriate expressive behavior.

\section{B. Restrictions on Fan Expression as Time, Place, and Manner Regulations}

If collegiate sports venues are limited public fora for First Amendment purposes, all government regulation of fan expression or cheering speech will be subject to constitutional scrutiny. However, to

160. See United States v. Grace, 461 U.S. 171, 177 (1983) (quoting Perry Educ. Ass'n v. Perry Local Educators' Ass'n, 460 U.S. 37, 45 (1983)).

161. Benedict \& McMillen, supra note 132, at 19 ("It is in this third category of public property that collegiate athletic sports venues fall for purposes of First Amendment free speech analysis.").

162. Id. at 20 .

163. See id.

164. Id. at 21-22.

165. Good News Club v. Milford Cent. Sch., 533 U.S. 98, 106-07 (2001). 
the extent all-out, content-neutral bans on such expression are imposed at collegiate sports venues, fans literally will have nothing to say because such restrictions on expression are constitutional. As of yet, no university has imposed an all-out ban of speech at college sporting events, and it is highly unlikely any school would ever venture that far. To do so and remain within the bounds of constitutional standards, all forms of expression would be suppressed and the stadiums of college football would be more like the fairways of professional golf in terms of spectator participation.

But some schools have made an attempt to censor sports fans' visual expression by restricting signs and banners from college sports venues. A brief survey of sign and banner policies at schools in the Big XII Conference, for example, reveals a variety of differing expression restrictions that likely fall well short of constitutional standards. The University of Missouri permits signs that can be held by one individual, reflect good sportsmanship, and do not contain vulgar, derogatory, or suggestive language. ${ }^{166}$ At the University of Colorado, fans are informed that "[h]and-held signs, banners, or flags that obstruct, endanger, or are offensive to other patrons will be confiscated." 167 At both Iowa State University and Kansas State University, all banners, placards, and leaflets not pre-approved by the athletics department are prohibited from school stadiums. ${ }^{168}$ These restrictions are not content-neutral bans of all signs, banners, and placards - rather, they ban only those signs, banners, and placards that are either vulgar, derogatory, suggestive, offensive, or that are not pre-approved, likely based upon similar standards. Because these regulations are content and viewpoint based, there is no need even to apply the strict scrutiny standard. If challenged, these policies likely would be held unconstitutional.

Other schools, however, have imposed content and viewpoint neutral restrictions on visual speech. The policy adopted by the University of Virginia, banning all signs and banners to promote sportsmanship and a positive game day environment, ${ }^{169}$ qualifies. So too does the University

166. University of Missouri, Football Ticket Policies and Procedures, http://mutigers.cstv.com/ tickets/footbl-policies-procedures.html\#7 (last visited Mar. 1, 2009).

167. University of Colorado, Folsom Field Policies and Information, http://www.cubuffs.com/ ViewArticle.dbml?DB_OEM_ID=600\&DB_OEM_ID=600\&ATCLID=24436 (last visited Mar. 1, 2009).

168. Iowa State University, Jack Trice Stadium Policies and Procedures, http://www.cyclones.com/ViewArticle.dbml?DB_OEM_ID=10700\&key=ATCLID=508900 (last visited Mar. 1, 2009); Kansas State University, Gameday Policies, http://www.kstatesports.com/ ViewArticle.dbml?DB_OEM_ID=400\&KEY=\&ATCLID=35616 (last visited Mar. 1, 2009).

169. See Christian, supra note 35. 
of Mississippi's ban on all flags and banners larger than twelve by fourteen inches, imposed to foster safety and eliminate the potential to obstruct the view of other spectators. ${ }^{170}$ But to pass the strict scrutiny test, these restrictions on visual cheering speech at collegiate sports venues must be narrowly tailored to serve a significant governmental interest and leave open alternative channels of communication.

\section{Significant Governmental Interests at College Stadiums}

In order to constitutionally regulate expression at a limited public forum, the government may impose content-neutral time, place, and manner restrictions that are narrowly tailored to serve a significant governmental interest. Proponents of speech regulation at collegiate sports venues argue that the government has significant interests in (1) protecting children from indecent language, ${ }^{171}$ (2) protecting the privacy interests of those watching or listening to the game from home, ${ }^{172}$ and (3) protecting fans from unsafe and hazardous environments. ${ }^{173}$

\section{a. Governmental Interest in Protecting the Well-Being of Minors}

Proponents first contend that, because of the high probability that children in the stands will be subjected to such language during games, universities have a justifiable interest in protecting children at collegiate athletic events from offensive language. ${ }^{174}$ They cite to Ginsberg v. New York $^{175}$ to argue that speech regulation should be justified in terms of protecting the "well-being" of minors. ${ }^{176}$ In Ginsberg, the Court held that a New York statute prohibiting the sale of sexually explicit material-deemed obscene for minors-to children under seventeen

170. See Tiffany, supra note 19 , at 119.

171. Calvert \& Richards, supra note 159 , at 18 ("[P]ublic universities instituting content-based restrictions on spectator expression at sports events should attempt to justify them in terms of protecting the well-being of minors in the audience... from offensive language."); Gregory Matthew Jacobs, Comment, Curbing Their Enthusiasm: A Proposal to Regulate Offensive Speech at Public University Basketball Games, 55 CATH. U. L. REV. 547, 568 (2006) ("[A] university has a justifiably substantial interest in protecting children at basketball games from offensive language.").

172. See Jacobs, supra note 171, at 565-66 ("As demonstrated by case law subsequent to Cohen, ... the $[\mathrm{u}]$ niversity could regulate on behalf of the privacy interests of those watching the game on television or listening to the game on the radio.").

173. Benedict \& McMillen, supra note 132, at 24 ("[T] he university could prohibit all signs as disruptive and interfering with viewing the event or affecting fan safety.").

174. Jacobs, supra note 171, at 568.

175. 390 U.S. 629 (1968).

176. Calvert \& Richards, supra note 159 , at 18. 
years old did not violate the free expression rights of minors. ${ }^{177}$ The Court recognized that " $[\mathrm{t}]$ he well-being of [the State's] children is of course a subject within the State's constitutional power to regulate."178 But obscene material is not protected speech, ${ }^{179}$ and it is unlikely that the profane expression at collegiate sports events rises to the level of depicting sexually explicit conduct appealing to the prurient interest of minors. ${ }^{180}$ In Ginsberg, the defendant was charged with selling magazines depicting female nudity to minors, ${ }^{181}$ but rowdy fans at a college football game are not holding signs with pornographic images to cheer on their teams.

Proponents' strongest argument focuses on other Supreme Court opinions that demonstrate that the Court has "recognized an interest in protecting minors from exposure to vulgar and offensive spoken language." 182 In Federal Communications Commission v. Pacifica Foundation, the Court held that a radio broadcast of satirical humorist George Carlin, describing sexual and excretory activities in a "patently offensive" manner during a time when children were likely in the audience, was vulgar, offensive, and shocking. ${ }^{183}$ The Court noted that because the broadcast media has a "uniquely pervasive presence" 184 in America, its unique accessibility to children ${ }^{185}$ and the government's interest in the well-being of its youth justifies the special treatment of indecent broadcasting. ${ }^{186}$ Regulating cheering speech under the premise that indecent, offensive, and profane fan expression will be broadcast over radio or television and reach children during a time when they are "in the audience" would be a possibility. The question, however, becomes, to what extent can fan expression actually be heard and understood during a broadcast? Do the potential lewd and vulgar cheers come through as if they were the actual content of the broadcast, or does

\footnotetext{
177. Ginsberg, 390 U.S. at 637.

178. Id. at 639 .

179. Miller v. California, 413 U.S. 15, 23 (1973) ("[O]bscene material is unprotected by the First Amendment."); see Pope v. Illinois, 481 U.S. 497, 500 (1987) (“"The First Amendment protects' works which, taken as a whole, have serious literary, artistic, political, or scientific value...." (quoting Miller, 413 U.S. at 34)).

180. See Pope, 481 U.S. at 500-01 ("[T]he first and second prongs of the Miller test-appeal to prurient interest and patent offensiveness - are issues of fact for the jury to determine applying contemporary community standards.").

181. Ginsberg, 390 U.S. at 631-32

182. See, e.g., Bethel Sch. Dist. No. 403 v. Fraser, 478 U.S. 675, 684 (1986).

183. Fed. Commc'ns Comm'n v. Pacifica Found., 438 U.S. 726, 747 (1978).

184. Id. at 748 .

185. Id. at 749 .

186. Id. at $747-50$.
} 
the expression become blurred in the background such that only the commentators calling the game can be understood?

Proponents also rely on Justice Powell's majority opinion in Erznoznik v. City of Jacksonville, where he wrote: "It is well settled that a State or municipality can adopt more stringent controls on communicative materials available to youths than on those available to adults." 187 In Erznoznik, the manager of a drive-in movie theater was charged with violating a municipal code for showing a motion picture, visible from the public streets, which depicted female nudity. ${ }^{188}$ But Justice Powell also noted that "only in relatively narrow and well-defined circumstances may government bar public dissemination of protected materials to [minors]." ${ }^{\prime 189}$ The Court found that even if the ordinance was aimed at prohibiting youths from viewing sexually explicit films, the restriction was broader than permissible because it forbade the display of all films containing any form of nudity. ${ }^{190}$ Justice Powell's opinion continued: "Speech that is neither obscene as to youths nor subject to some other legitimate proscription cannot be suppressed solely to protect the young from ideas or images that a legislative body thinks unsuitable for them." 191

There is little question that collegiate football and basketball venues are locations where parents can bring their children for fun and exciting family outings. Many universities even target this demographic by offering special ticket packages specifically for families that prefer to sit in pre-designated family-friendly areas of the stadium. ${ }^{192}$ But, by allowing lewd, vulgar, and offensive cheering speech to echo throughout their sports venues, public universities run the risk of losing this demographic of fans who do not want their children exposed to profane and indecent expression.

As Ginsberg, Pacifica, and Erznoznik indicate, the Court has recognized a significant interest in protecting the well-being of minors. However, even despite this significant interest, the existing government regulations on expression at collegiate sporting events are not necessarily narrowly drawn to achieve that interest. Those restrictions that are actually content-neutral, such as the complete ban on all signs and

187. Erznoznik v. City of Jacksonville, 422 U.S. 205, 212 (1975).

188. Id. at 206 .

189. Id. at 213

190. Id.

191. Id. at 213-14.

192. See, e.g., The University of Kansas Official Athletic Site, http://kuathletics.cstv.com/ tickets/kan-footbl-season-tix.html (last visited Jan. 18, 2009) (describing KU's Family Plan, which "includes two adult and two youth general admission season tickets"). 
banners at the University of Virginia, serve to eliminate all visual messages that a child fan may see, but they do nothing to protect that same child from the echoing chants, cheers, and yells-such as Maryland's "Fuck Duke," 193 Kansas's "Rip His [Fucking] Head Off,"194 and others - which will remain present within college stadiums and arenas. In fact, the majority of examples in this Comment refer to offensive chants and cheers found among student sections across the country, not to signs or banners. Thus, assuming such regulations are aimed at protecting the well-being of minors, they ultimately fall short of achieving their purpose. Only an all-out ban on fan expression at college sports events could be both content-neutral and designed to protect children from exposure to profane, indecent, and vulgar expression. But such a restriction is impractical because it would remove the spirit, pride, and excitement that fan participation exudes at collegiate athletic events.

b. Governmental Interest in Protecting the Privacy Interests of Those Watching or Listening from Home

Proponents further contend that universities have a justifiable interest in protecting the privacy interests of an individual watching or listening to a collegiate athletics game from his or her home. ${ }^{195}$ They place reliance on the Court's opinion in Pacifica and Justice O'Connor's majority opinion in Frisby v. Schultz, ${ }^{196}$ which states:

One important aspect of residential privacy is protection of the unwilling listener. Although in many locations, we expect individuals simply to avoid speech they do not want to hear, the home is different. "That we are often 'captives' outside the sanctuary of the home and subject to objectionable speech ... does not mean we must be captives everywhere." ... Thus, we have repeatedly held that individuals are not required to welcome unwanted speech into their own homes and that the government may protect this freedom. ${ }^{197}$

In Frisby, the City of Brookfield, Wisconsin, enacted an ordinance which completely banned picketing within residential areas after a group of people strongly opposed to abortion had picketed outside the home of a

193. Benedict \& McMillen, supra note 132, at 5.

194. Andy Hyland, Mangino At Center of Drive to Silence Obscene Chant at KU Football Games, LAWRENCE J.-WORLD, Oct. 8, 2008, at 1A.

195. Jacobs, supra note 171, at 565-66.

196. 487 U.S. 474 (1988).

197. Id. at 484-85 (citations omitted). 
doctor known to perform abortions. ${ }^{198}$ Relying on the Captive Audience Doctrine, the Court deemed the doctor to be "figuratively, and perhaps literally, trapped within [his] home, ${ }^{, 199}$ and upheld the ban. ${ }^{200}$

Proponents of regulating fan expression argue that sports fans watching games from home are similarly trapped when unwelcome offensive speech is broadcast into their homes. "To say that one may avoid further offense by turning off the radio when he hears indecent language is like saying that the remedy for an assault is to run away after the first blow.... [B] [ut that option does not ... [allow the listener to] avoid a harm that has already taken place."201

But college sports fanatics engaging in offensive expression are not cheering and chanting on the doorsteps of anyone's home, and whether the rationale in Pacifica applies is to be evaluated upon consideration of "a host of variables": "The time of day, ... [t] he content of the program in which the language is used,... and [the] differences between radio [and] television." 202 These variables all favor regulation because sports games are broadcast during the day and in prime time when networks can attract the most viewers or listeners. Also, college sports broadcasts attract a wide-ranging group of people who tune in to watch a competition, not to view offensive material on signs and banners displayed in the crowd or listen to offensive language as listeners of a George Carlin comedy routine might expect. Furthermore, the differences between television and radio are relevant only to the visual aspect of a college athletics broadcast. The content-neutral restriction on signs and banners at the University of Virginia could be justified under the privacy of the home rationale because viewers at home would not be subject to offensive signs when television camera crews show images of the crowd.

But, as stated above, much of the offensive material present at collegiate athletic events comes in the form of cheers and chants, not signs and banners, and it may be that the privacy of the home rationale would not apply to restrictions on verbal expression. The game and the commentary of the announcers in the booth represent the primary content to be broadcast, with the offensive material looming in the background. Thus, the policy rationale for protecting the sanctity of the home will only apply if the offensive material can be heard and understood when

\footnotetext{
198. Id. at 476 .

199. Id. at 487 .

200. Id. at 488 .

201. Fed. Commc'ns Comm'n v. Pacifica Found., 438 U.S. 726, $748-49$ (1978).

202. Id. at 750 .
} 
broadcast into the homes of unwilling listeners. But a university has yet to impose a content-neutral restriction on verbal fan expression and likely will not do so in order to preserve the long-standing tradition of school yells and chants that are neither offensive nor indecent.

c. Governmental Interest in Protecting Fans from Unsafe Environments and Viewpoint Obstructions

Finally, proponents of regulating fan expression effectively argue that protecting fans from unsafe and hazardous environments is a significant governmental interest justifying content-neutral restrictions on speech. ${ }^{203}$ The University of Mississippi followed this rationale when it invoked a restriction on all flags and banners larger than twelve by fourteen inches at university athletic events. ${ }^{204}$ The restriction was imposed to prevent injuries from flagsticks and address complaints about obstructing the views of other spectators. ${ }^{205}$ The U.S. District Court that presided over a lawsuit over the policy explained that the ban's purpose of safety and control of the spectators within the stadium reflected the university's substantial interest in safe and efficient game management. ${ }^{206}$

This restriction does not target offensive, vulgar, or indecent visual material, but serves to eliminate all forms of visual expression in the form of a flag or large sign to protect fans and ensure that everyone has the ability to observe the competition. Fans at the University of Mississippi are, however, still permitted to express themselves visually by holding a sign that conforms to the restriction, including one of an image of a flag or some other message that may be considered offensive. However, officials at the University of Virginia trying to rely on a similar rationale for their complete ban on signs and banners would face challenges that the school's policy is overbroad. The school would have to justify that all signs and banners, regardless of size, pose either a safety risk to other fans or will obstruct the view of other fans.

In sum, the Court has recognized significant governmental interests that may be used by public universities to regulate fan expression at school athletic events. With regard to visual speech (signs, banners, and

203. Benedict \& McMillen, supra note 132, at 24 ("[T] he university could prohibit all signs as disruptive and interfering with viewing the event or affecting fan safety.").

204. Barrett v. Khayat, No. CIV.A. 397CV211BA, 1999 WL 33537194, at*1 (N.D. Miss. Nov. $12,1999)$

205. Id.

206. Id. at *4. 
flags), the governmental interests in protecting (1) the well-being of minors, ${ }^{207}$ (2) the privacy interests of those watching from home on television, ${ }^{208}$ and (3) fans from unsafe environments may be and have been utilized by public institutions to justify bans on visual expression in the stands. But the verbal-expression issue (chants, cheers, and yells) has yet to be addressed by public universities in the form of all-out bans on speech. While schools could constitutionally do so in furtherance of the well-being of minors or possibly the privacy interests of those watching or listening to games at home, the result would be to silence the stadiums and arenas across the country and drastically change the dynamic and appeal of the games.

\section{Alternative Channels of Communication}

Even if the government imposes regulations on fan expression that are narrowly tailored to further a significant governmental interest, it must leave open alternative channels of communication. For example, the University of Mississippi's ban on all large signs and flags leaves fans with the option of bringing smaller signs, including signs with an image of the flag. Fans would also be able to verbally deliver their messages, wear their messages on their clothing, or display their flags and large signs in the parking lot outside of the stadium. The University of Virginia's ban on signs and banners leaves fans similar options to either express themselves verbally, through their clothing and apparel, or outside the stadium before, during, and after the games. However, students at the university found another and more creative channel of communication when nearly 5000 students held up eleven by seventeen inch sheets of blank, white paper in protest of the school's anti-sign policy. $^{209}$

With the exception of expression options outside the stadium, the alternative channels available for fan expression inside the stadium are also currently at issue. As discussed above, offensive chanting and cheering at collegiate sporting events is arguably a bigger issue than sign and banner expression, as student sections across the country have adopted the use of profanity to target opposing teams, referees, and

207. See Ginsberg v. New York, 390 U.S. 629, 639 (1968) (restricting the rights of minors to access obscene materials).

208. Frisby v. Schultz, 487 U.S. 474, 484 (1988); Fed. Commc'ns Comm'n v. Pacifica Found., 438 U.S. 726, 749-50 (1978).

209. Zach Rowen, Reporting From... the UVA Sign-Ban Protest, ESPN THE MAG., http://sports.espn.go.com/espnmag/story?id=3575560 (last visited Feb. 25, 2009). 
others. Speech through fan apparel is gaining criticism as well, prompted by things such as Ohio State students sporting t-shirts reading "Ann Arbor is a Whore," ${ }^{110}$ Kansas students wearing apparel reading "Muck Fizzou," display a picture of Lawrence, Kansas, burning in William Quantrill's raid of $1863^{212}$ - with the word "Scoreboard" and a University of Missouri logo appearing immediately below. ${ }^{213}$

It is unlikely and virtually impossible for public universities to institute bans on verbal and apparel-based expression. From a historical perspective, college sporting events have always had a rich tradition of school spirit and fan participation. School fight songs, yells, and other traditions have been around for decades and are a part of the university culture. From a financial perspective, the money to be gained from fans purchasing school t-shirts, hats, jackets, and other accessories is immense and a complete ban on apparel-based expression would likely result in significant profit losses for universities and would not be worth the restriction.

\section{Proposals to Solve the "Cheering Speech" Issue that May Pass Constitutional Standards but Fail Public Opinion}

To assist universities in resolving the dispute between expressive fans and unwilling listeners, some scholars have proposed "Model Regulations" ${ }^{, 14}$ for schools across the country to adopt, which they argue satisfy constitutional requirements. The problem, however, is that many of these proposals will not pass the test of satisfying public opinion. While these calculated restrictions will serve to provide content-neutral prohibitions, their practical application at the stadium on game day would not be well received.

For example, one such model policy would rely on the captive audience doctrine to enact regulations that prohibit indecent, obscene, and profane speech while attending university athletic events. ${ }^{215}$ The proponents argue that because substantial individual privacy interests are being invaded by "inappropriate" fan expression, both within homes and

\footnotetext{
210. Torline, supra note 28.

211. Weslander, supra note 29.

212. Diepenbrock, supra note 30

213. Id.

214. See Calvert \& Richards, supra note 159, at 27 (discussing the status of "fighting words" as unprotected speech); Jacobs, supra note 171, at 564-66 (discussing regulations in terms of protecting a substantial privacy interest).

215. Jacobs, supra note 171, at 575.
} 
at the game, regulation is required. ${ }^{216}$ The proponents rely on the Court's opinion in Denver Area Educational Telecommunications Consortium, Inc. v. Federal Communications Commission ${ }^{217}$ that unwilling listeners of public television and radio broadcasts are considered a captive audience and, while viewers are free to avert their eyes, ${ }^{218}$ such an argument, according to the Court, "is the equivalent to saying that the remedy to an assault is to run away after the first blow." 219

The proponents further argue that children attending the game are similar to the transit passengers in Lehman v. Shaker Heights, ${ }^{220}$ and the students in Bethel School District No. 403 v. Fraser, ${ }^{221}$ such that the "obscene message engages children who have no means of avoiding the conduct." 222 But fans at university sporting events are not a captive audience. Fans have the option to avert their eyes ${ }^{223}$ from messages they do not want to see, listen to the radio broadcast while at the game using headphones to dilute the cheers, or simply not go to the game at all.

Another policy "prohibits all spectators from bringing into any athletic arena or stadium any banners, signs, or posters, regardless of their content or subject-matter." 224 The policy, however, would allow fans to bring and display such banners outside of the sports venues. ${ }^{225}$ It is possible this regulation would pass constitutional muster. The government has a significant interest in protecting student athletes, coaches, and referees from verbal abuse and threats as well as children in the audience who would otherwise be exposed to potentially offensive language. The all-out ban on all signs is a content-neutral policy, and it has left open alternative methods to display such banners and signs, such as the parking lot. But is this regulation narrowly drawn to further the interest? Unfortunately, no. While the ban on signs and banners removes visually offensive material (and other "appropriate" visual material) from the confines of the stadium, the auditory offensive material in the form of cheers, chants, and yells will remain. So those same classes of people that the state is trying to protect will continue to

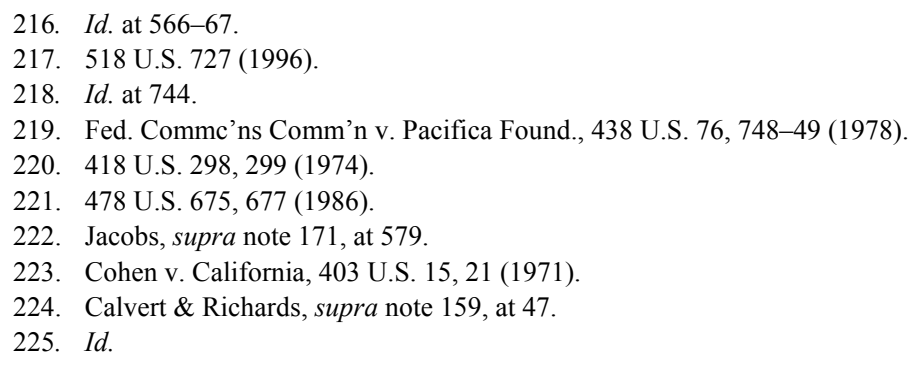


be exposed to the "inappropriate" material that the regulation is designed to prohibit.

The policy also imposes restrictions on clothes-based expression, requiring that spectators who wear any article of clothing at sporting events "bearing any words with letters larger in height or width than one inch, regardless of the content or subject matter ... must sit in seats at least 25 rows away from the court or playing field." ${ }^{\text {,26 }}$ The policy rationale is to reduce the likelihood that indecent and profane messages are broadcast to a television audience across the country. ${ }^{227}$ But the practical implementation of this content-neutral policy would be impossible for stadium officials to enforce and it would also result in very few fans with team apparel sitting within the first twenty-five rows of the field. Furthermore, such a restriction would not be in the interests of university officials, who would want the name and logo of their institution displayed proudly on the shirts and hats of fans throughout the stadium, not just rows twenty-five and up. In 2007, officials at the University of Kansas were asked by ESPN television to make an announcement asking the students to turn their "Muck Fizzou" shirts inside-out during a home basketball game. ${ }^{228}$ While the KU athletics department considered the shirt "distasteful," it declined to make the announcement. ${ }^{229}$

\section{An American Solution: More Speech}

An ideal solution to the spectator expression issue facing public university administrators would strike an appropriate balance in preserving long-standing constitutional rights, while at the same time furthering strong governmental interests. However, to the extent that these principles collide and co-existence becomes impossible, it is inevitable that one must ultimately yield to the other. Should sports fans, like the KU student with his banner, suffer the loss and be censored from expressing their views, many of which contain clean, clever, and often truthful statements? Or should universities acknowledge the commands and the restrictions imposed on them by the provisions of the First Amendment and work toward seeking other alternatives? The answer must be the latter.

228. Weslander, supra note 29

229. Id. 
A determination that governmental interests-like protecting student athletes, coaches, referees, and child spectators from rude, profane, and insulting expression-outweigh the constitutional guarantees of free speech and expression would itself be unsportsmanlike. The prohibition of all signs and banners, like at the University of Virginia, while a content-neutral regulation, is too broad a restriction and fails to accomplish its targeted goals. What about a restriction prohibiting all chants and cheers at sports events, whether positive or negative, to ensure that all "inappropriate" language is eliminated from speech that unwilling listeners would receive? While these proposals would serve to further the governmental interests, they are overbroad restrictions on American speech. The only restrictions on expression that university officials should lawfully regulate are those forms of expression the Supreme Court has already determined receive no protection: defamation, obscenity, fighting words, and illegal advocacy intended to incite imminent lawless action.

The proper solution is a traditional American solution-more speech. Ample alternatives exist for athletics officials and university administrators to mitigate the negative effects of free expression. The strongest alternative would be to counter negative, profane, and unwanted student speech with university approved messages. The university could easily generate such messages through its cheerleaders, marching bands, and sound-systems, as well as by creating an official student cheering section to help drown out the speech the university seeks to eliminate. Officials at the University of Arkansas have taken this approach in encouraging cheerleaders and band members to "help dissuade or drown out negative cheers and taunts with their own positive cheers and music." 230

Secondly, a public university has complete authority to zone its facilities and determine which groups - students, families, alumni, valuable donors, etc. - sit in which sections. While a complete dissolution of the student section at athletic events is an option to dissipate unwanted expression, such action would serve to eliminate potential home-field advantages schools strive to create. A better option would be to separate the students from the families, minimize exposure, and utilize the school marching band by placing it near the students to drown out any "inappropriate cheering speech." Athletics officials at the

230. Eric W. Aho, A Descriptive Analysis of the Fourteen Mid-American Conference Athletic Band Programs 64 (2005) (unpublished Ph.D. dissertation, The Ohio State University) (on file with author). 
University of Illinois have taken such steps by shifting the students and band away from the visiting players and fans. ${ }^{231}$

Thirdly, many schools have begun appealing to students via pregame video announcements from popular and well-respected members of the university, such as head coaches. Such messages may not persuade every spectator, but the university has every right and reason to encourage sportsmanlike behavior from its fans. Furthermore, the university could target forms of speech such as profanity and sexist, racist, or other derogatory language without implicating First Amendment protections simply by encouraging students to refrain from such behavior. This option serves as a deterrent and helps to educate vocal and passionate fans about preferred conduct while in attendance.

Finally, universities should consider implementing sportsmanship initiatives to promote sportsmanlike behavior and foster a positive, yet competitive, game day environment. The University Daily Kansan, the student newspaper at $\mathrm{KU}$, began a campus-wide contest to replace the popular, yet offensive "Muck Fizzou" t-shirt. ${ }^{232}$ Students were encouraged to submit design ideas and vote for their favorites online. ${ }^{233}$ A KU Associate Athletic Director believed "the contest was a step in the right direction," stating that the athletics department "[thought] the best part of this was that it was totally student driven, and that is the way it should be." 234 Similarly, students at the University of Maryland created a "voluntary compliance policy," which included a profane t-shirt exchange; contests encouraging students to design clever signage; having popular athletics representatives address the students about good sportsmanship; and distributing lists of "creative witty cheers" for students to proclaim at home games. ${ }^{235}$ In 2004, Maryland State University spent over $\$ 30,000$ on a campus-wide "sportsmanship" campaign $^{236}$ and in 2003, the Big Ten Conference also launched a sportsmanship program. ${ }^{237}$

231. Id. at $63-64$

232. Thor Nystrom, Out with 'Muck Fizzou, 'Students Vote for the New, U. DAILY KANSAN, Oct. 25,2007 , at $3 \mathrm{~A}$.

233. Id.

234. Thor Nystrom, Winning Slogans Revealed for Rivalry, Gameday T-Shirts, U. DAILY KANSAN, Nov. 12, 2007, at 10A.

235. Wasserman, supra note 14, at 390-91.

236. Ethan Yale Bordman, Freedom of Speech and Expression in Sports: The Balance Between Rights of the Individual and the Best Interest of Sport, 86 MICH. BAR J. 36, 37 (Sept. 2007).

237. Calvert \& Richards, supra note 159 , at 3. 


\section{CONCLUSION}

Collegiate athletics are a source of great pride, loyalty, and school spirit for many Americans. Every week, thousands across the country file into the stands, fill the seats, and choose to express their passion for the game and their teams in many different ways. For some, boisterous boos, obnoxious chants, and profane messages are the means for fans to fully express themselves. For others, singing the school fight song, participating in the traditional school yell, and applauding the team on to victory, all while wearing the school colors, is the preferred mode of expression. The First Amendment to the Constitution allows each person to freely express himself or herself, even at sporting events, subject to government regulations that are content-neutral, further significant governmental interests, and leave open alternatives modes of communication.

Despite the constitutional ability of schools to regulate speech to protect players, coaches, referees, and child spectators from "inappropriate" remarks during games using content-neutral restrictions, universities should look to other alternatives. Restrictions on such speech cannot be viewpoint based. Thus, to achieve the desired result of no indecent, vulgar, or profane language at college sports events, universities must impose overbroad policies that will censor even the most humorous, clever, and even truthful expression about the game, players, teams, or schools. The proper remedy to combat negative speech is more speech. Schools have ample resources to counter "inappropriate speech" by creating positive cheers and chants, implementing sportsmanship initiative programs, zoning their stadiums, and appealing to students through well-respected members of the school or community and encouraging all fans to act with class. To do otherwise would be unsportsmanlike. 